University of Nebraska - Lincoln

DigitalCommons@University of Nebraska - Lincoln

USGS Staff -- Published Research

US Geological Survey

2014

\title{
Habitat coupling in a large lake system: delivery of an energy subsidy by an offshore planktivore to the nearshore zone of Lake Superior
}

Jason Stockwell

University of Vermont, jason.stockwell@uvm.edu

Daniel Yule

USGS Great Lakes Science Center

Thomas Hrabik

University of Minnesota - Duluth

Michael Sierszen

National Health and Environmental Effects Research Laboratory, Mid-Continent Ecology Division, United States

Environmental Protection Agency

Edmund Isaac

Grand Portage Band of Lake Superior Chippewa

Follow this and additional works at: http:// digitalcommons.unl.edu/usgsstaffpub

Stockwell, Jason; Yule, Daniel; Hrabik, Thomas; Sierszen, Michael; and Isaac, Edmund, "Habitat coupling in a large lake system: delivery of an energy subsidy by an offshore planktivore to the nearshore zone of Lake Superior" (2014). USGS Staff -- Published Research. 844.

http://digitalcommons.unl.edu/usgsstaffpub/844

This Article is brought to you for free and open access by the US Geological Survey at DigitalCommons@University of Nebraska - Lincoln. It has been accepted for inclusion in USGS Staff -- Published Research by an authorized administrator of DigitalCommons@University of Nebraska - Lincoln. 


\title{
Habitat coupling in a large lake system: delivery of an energy subsidy by an offshore planktivore to the nearshore zone of Lake Superior
}

\author{
JASON D. STOCKWELL*, DANIEL L. YULE ${ }^{\dagger}$, THOMAS R. HRABIK $^{\ddagger}$, MICHAEL E. SIERSZEN $^{\S}$ AND \\ EDMUND J. ISAAC ${ }^{\mathbb{I}}$ \\ *Rubenstein Ecosystem Science Laboratory, University of Vermont, Burlington, VT, U.S.A. \\ ${ }^{\dagger}$ Lake Superior Biological Station, USGS Great Lakes Science Center, Ashland, WI, U.S.A. \\ ${ }^{\ddagger}$ Department of Biology, University of Minnesota, Duluth Campus, Duluth, MN, U.S.A.

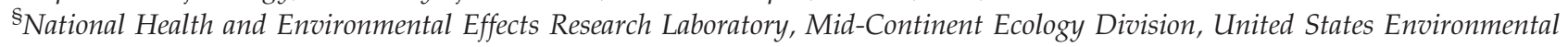 \\ Protection Agency, Duluth, MN, U.S.A. \\ ${ }^{\mathbb{I}}$ Grand Portage Band of Lake Superior Chippewa, Grand Portage, MN, U.S.A
}

\section{SUMMARY}

1. We hypothesised that the autumn spawning migration of Lake Superior cisco (Coregonus artedi) provides a resource subsidy, in the form of energy-rich cisco eggs, from the offshore pelagic to the nearshore benthic community over winter, when alternate prey production is likely to be low.

2. We tested this hypothesis using fish and macroinvertebrate surveys, fish population demographics, diet and stable isotope analyses, and bioenergetics modelling.

3. The benthic, congeneric lake whitefish (C. clupeaformis) was a clear beneficiary of cisco spawning. Cisco eggs represented $16 \%$ of lake whitefish annual consumption in terms of biomass, but $34 \%$ of energy (because of their high energy density: $>10 \mathrm{~kJ} \mathrm{~g}$ wet mass $^{-1}$ ). Stable isotope analyses were consistent with these results and suggest that other nearshore fish species may also rely on cisco eggs.

4. The lipid content of lake whitefish liver almost doubled from 26 to $49 \%$ between November and March, while that of muscle increased from 14 to $26 \%$ over the same period, suggesting lake whitefish were building, rather than depleting, lipid reserves during winter.

5. In the other Laurentian Great Lakes, where cisco populations remain very low and rehabilitation efforts are underway, the offshore-to-nearshore ecological link apparent in Lake Superior has been replaced by non-native planktivorous species. These non-native species spawn in spring have smaller eggs and shorter incubation periods. The rehabilitation of cisco in these systems should reinstate the onshore subsidy as it has in Lake Superior.

Keywords: cisco, eggs, foraging, whitefish, winter ecology

\section{Introduction}

The transfer of energy across habitats can have important consequences for ecological community dynamics and ecosystem processes (e.g. Polis, Anderson \& Holt, 1997). For example, predators can alter ecosystem properties across habitats directly through consumption and the translocation of nutrients, and indirectly through predator-induced prey habitat and foraging shifts effects
(Schmitz et al., 2008; Schmitz, 2010). Connections between different habitats also may facilitate the export of primary production to food-limited habitats, resulting in greater overall production than would be the case with disconnected habitats (e.g. Cloern, 2007).

Highly mobile organisms such as fish can couple seemingly disconnected habitats. Semelparous Pacific salmon (Onchorynchus spp.) move marine-derived nutrients to coastal ecosystems where they have a significant

Correspondence: Jason D. Stockwell, Rubenstein Ecosystem Science Laboratory, University of Vermont, 3 College Street, Burlington, VT 05401, U.S.A. E-mail: jason.stockwell@uvm.edu 
impact on freshwater and terrestrial production (e.g. Kline et al., 1993). Similarly, migratory iteroparous fish, such as alewife (Alosa pseudoharengus; Durbin, Nixon \& Oviatt, 1979), blueback herring (A. aestivalis; MacAvoy et al., 2000) and rainbow smelt (Osmerus mordax; Saunders, Hachey \& Fay, 2006), move nutrients and may be taken by predators as they move within and among habitats seasonally. In addition to nutrients, egg deposition may represent significant pulses of food resource in coastal marine (e.g. Willson \& Womble, 2006) and river (Heintz, Wipfli \& Hudson, 2010) systems. In lakes, energy fluxes between benthic and pelagic habitats facilitated by fish movement are considered important processes in whole-lake food webs (e.g. Schindler \& Scheuerell, 2002).

Loss of native fishes resulting from overfishing or invasive species may disrupt ecological processes (Zimmerman \& Krueger, 2009). For example, cisco (Coregonus artedi) was a major component of fish assemblages in all the Laurentian Great Lakes (Smith, 1995) but collapsed by the middle of the 20th Century in most of the lakes (Lawrie \& Rahrer, 1973). Among the Laurentian Great Lakes, Superior is unique because its food web is currently dominated by native species, including rehabilitated cisco populations (Stockwell et al., 2009). Cisco are an important prey for native piscivores because their relatively large size provides a high net energy return (Mason, Johnson \& Kitchell, 1998; Kaufman et al., 2006). Additionally, a diet of cisco, compared to one of non-native species, such as alewife, does not induce thiaminase-related recruitment failure in piscivores (e.g. Brown et al., 2005), a condition similar to M74 syndrome in Baltic salmon (Salmo salar; e.g. Lundström et al., 1999). Thus, the presence of cisco in Lake Superior provides an opportunity to test hypotheses about the role of native fish in habitat coupling and ecosystem processes in a large lake environment.

In this study, we examined the role of cisco in the movement of energy from offshore to nearshore habitats. Adult cisco are primarily planktivorous (e.g. Gamble et al., 2011a), occupy offshore pelagic waters in Lake Superior (Stockwell et al., 2006; Stockwell et al., 2010) and move nearshore to spawn in late autumn (Yule et al., 2009). Their eggs incubate over winter and hatch in April and May and thus may provide an energy-rich resource for benthic predators from late autumn to spring. Previous studies in Lake Superior and the other Great Lakes indicate the macroinvertebrates Mysis and Diporeia are important prey for fish from spring to autumn (e.g. Owens \& Dittman, 2003; Gamble et al., 2011a,b; Isaac et al., 2012). Therefore, we hypothesised that cisco eggs act as a resource subsidy and support the nearshore benthic community in winter, when macroinvertebrate production is likely to be low (Stockwell et al., 2010). If true, cisco eggs should be an important diet for benthic fish throughout winter. Additionally, if cisco eggs have stable isotopic values distinct from invertebrate prey, this should be reflected in isotopic values of benthic fish between autumn and spring. In particular, cisco eggs should have a higher $\delta^{15} \mathrm{~N}$ than invertebrate prey, reflecting their higher trophic status, and a lower $\delta^{13} \mathrm{C}$ because of the pelagic origin of their carbon (France, 1995) and high lipid content. Alternatively, the nearshore production of benthic invertebrate prey may be sufficiently high that the comparative contribution of cisco eggs is negligible. We would then expect to see the winter diet of benthic fish dominated by invertebrates and their stable isotopic values reflecting that diet. We test these hypotheses using results from fish and macroinvertebrate surveys, fish population demographics, diet and stable isotope analyses, and bioenergetics modelling and discuss the consequences of our findings with regard to the importance of native fish in ecosystem processes.

\section{Methods}

\section{Study system}

Lake Superior is the largest freshwater lake by area in the world $\left(82000 \mathrm{~km}^{2}\right)$, averages $150 \mathrm{~m}$ in depth, and is highly oligotrophic (Munawar, 1978). This study was conducted within the Wisconsin south shore region in the western arm of the lake, which is characterised by a mix of nearshore $(<80 \mathrm{~m})$ and offshore $(>80 \mathrm{~m})$ habitats (Fig. 1). Cisco currently represent $63 \%$ of the total fish biomass in offshore areas in the western arm (T.R. Hrabik, unpubl. data), the amphipod Diporeia spp. represent $50 \%$ of benthic invertebrate biomass in the 0-80 $\mathrm{m}$ stratum of the western arm (J.V. Scharold, unpubl. data), and overall biomass of the diel vertical migrator Mysis diluviana is five to six times that of Diporeia (Kelly et al., 2011).

\section{Macroinvertebrate sampling}

Details of our sampling of Mysis and Diporeia can be found in Isaac et al. (2012). Briefly, Mysis was sampled at night with a vertically towed $1-\mathrm{m}^{2}$ net $(1000-\mu \mathrm{m}$ mesh tapered to $250-\mu \mathrm{m}$ mesh with a $63-\mu \mathrm{m}$-mesh bucket) from $2 \mathrm{~m}$ off bottom to the surface, and Diporeia was sampled during the day with a $0.046-\mathrm{m}^{2}$ Ponar grab. For 
Fig. 1 Study area along the Wisconsin south shore in the western arm of Lake Superior. (a) Sampling sites for Mysis and Diporeia biomass estimates, lake whitefish density estimates, and fish and invertebrates stable isotope samples. (b) Acoustic transects and density estimates of spawning-sized cisco (from Yule et al., 2009). Note different spatial scales between the two panels.

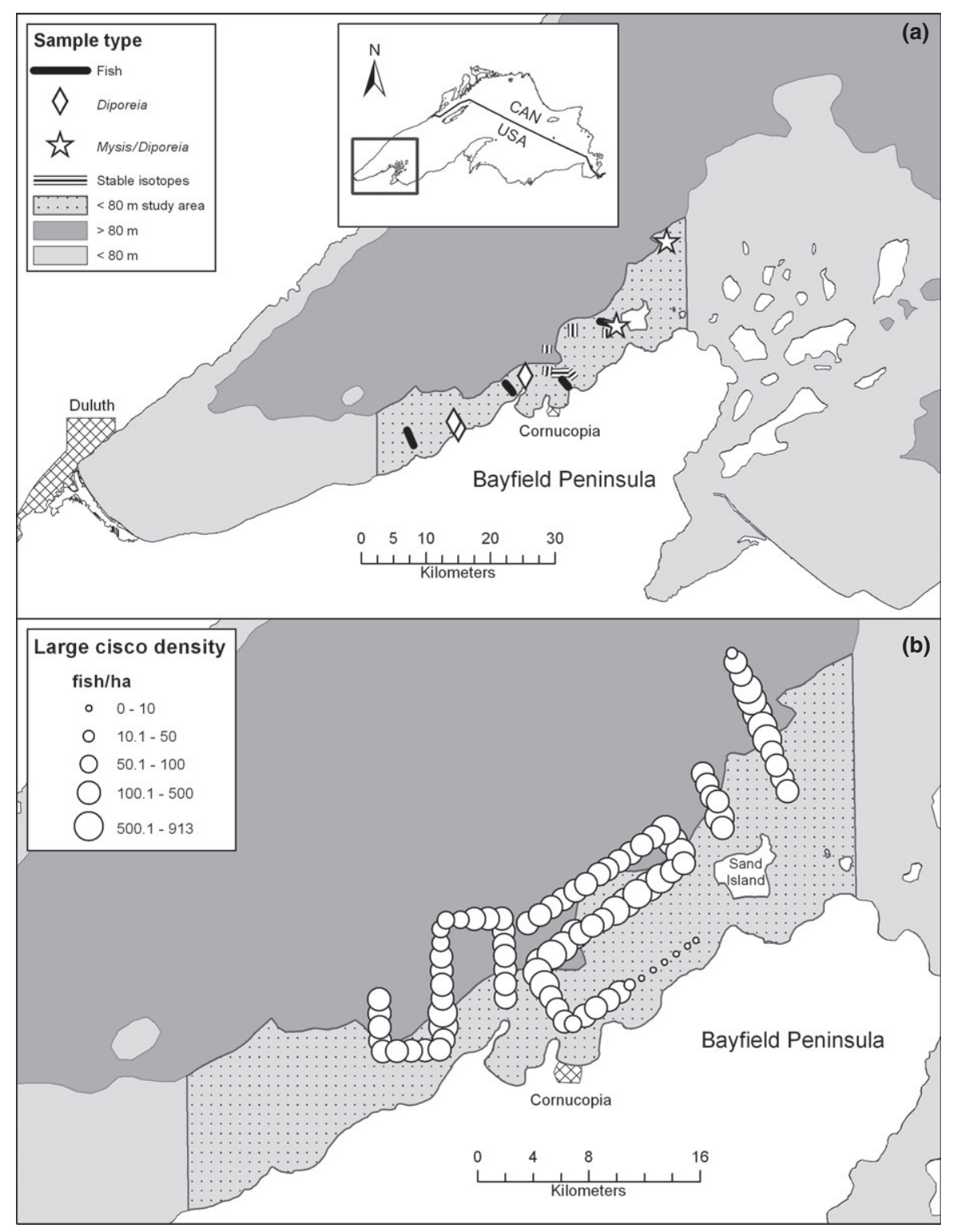

each Mysis and Diporeia sample, all individuals were counted and measured. We used mass-length regressions (USGS Great Lakes Science Center and DuluthEPA, unpubl. data) to convert individual lengths of Mysis and Diporeia to dry mass and to estimate the biomass $\left(\mathrm{kg} \mathrm{ha}^{-1}\right)$ of each. Mysis and Diporeia were collected at two and five sites, respectively (Fig. 1). One Mysis site was sampled in spring, summer and autumn of 2005, and the other site was sampled only in autumn that year. One Diporeia site was sampled in each of the three seasons, one site was sampled only in the autumn, and the remaining Diporeia sites were sampled only in the summer of 2005. Four (Mysis) and three (Diporeia) replicate samples were collected during each sampling event at each site. Replicates were used to estimate the mean biomass for each macroinvertebrate for each site/ season, and each of these site/season estimates was then used to estimate the annual mean $( \pm \mathrm{SE})$ biomass for $M y$ sis $(N=4)$ and Diporeia $(N=7)$. Annual mean biomass per unit area was then multiplied by the area of the Wisconsin south shore $<80 \mathrm{~m}$ (45 $760 \mathrm{ha}$ ) to estimate the overall annual biomass $(\mathrm{kg})$.

\section{Cisco spawning movements}

Cisco abundance in the nearshore habitat increases drastically between early and late autumn in Wisconsin waters of Lake Superior (Yule et al., 2009). The spawning cisco population of the western arm was estimated during November 2006 using acoustic methods and 
midwater trawl samples (see Yule et al., 2009). Adult cisco $(\geq 250 \mathrm{~mm})$ densities were estimated at 93 and 133 fish $\mathrm{ha}^{-1}$ for nearshore $(<80 \mathrm{~m})$ and offshore $(>80 \mathrm{~m})$ zones, respectively. For the present study, we used observations from Yule et al. (2009) to estimate mean $( \pm$ SE) adult cisco density in the study area (Fig. 1b). We assumed all adults spawned and all spawning occurred in the nearshore zone (Stockwell et al., 2009; Yule et al., 2012). Cisco caught in midwater trawl samples during the 2006 survey were processed to determine sex ratio, size structure and mass-length relationships, following Yule et al. (2008). Ovaries were collected to develop a mass versus fecundity relationship, following Yule et al. (2006), and to estimate egg energy density with bomb calorimetry (Parr 6200 Oxygen Bomb Calorimeter; Parr Instrument Company, Moline, IL, U.S.A.). Data were used to estimate the biomass of eggs deposited and their energetic equivalence assuming all eggs were spawned. Yule et al. (2006) found a majority of the variance associated with estimates of cisco egg deposition in the Apostle Islands region of Lake Superior resulted from variance in estimates of spawner density. Therefore, we estimated the variance in egg deposition based on the variance in spawner density alone and assumed that the variance in the other factors (sex ratio, size structure, the mass-length relationship and the mass-fecundity relationship) contributed negligibly to uncertainty in egg deposition.

\section{Lake whitefish sampling}

Numerical densities of lake whitefish (C. clupeaformis; hereafter 'whitefish') were estimated from an annual spring bottom trawl survey of the nearshore zone, conducted during daylight by the U.S. Geological Survey Great Lakes Science Center (see Stockwell et al., 2007 for details) that included four sites along the Wisconsin south shore (Fig. 1). We averaged density estimates from 3 years (2005-07) to smooth among-site and interannual variability in the years surrounding the 2006 cisco spawner survey. Abundance was calculated by multiplying mean density by the area of the study region (45 760 ha). These estimates were then used to scale up individual whitefish consumption estimates (see below).

Samples of whitefish diet in winter were taken from fish caught commercially near Sand Island (Fig. 1) between December 2009 and April 2010, with an additional collection there in December 2011. Whitefish were harvested with overnight bottom-set gill nets, except in one instance when fish were harvested by trap net (April 2010). Fish were returned to the laboratory for immediate processing. Stomach contents were emptied into a Petri dish, and prey items were sorted, blotted and weighed to the nearest $0.01 \mathrm{~g}$. Diet proportions were summarised by month from December to April, pooling across years when available.

\section{Consumption estimates}

Isaac (2010) recently estimated lake-wide, annual prey consumption by Lake Superior fish using a bioenergetics modelling approach. Here, we refine that work to estimate consumption by whitefish resident along the Wisconsin south shore. Estimates of whitefish consumption were developed with the Wisconsin bioenergetic model (Kitchell, Stewart \& Weininger, 1977) using the parameters for a generalised coregonid (Rudstam, Binkowski \& Miller, 1994), except that we applied the respiration parameter for whitefish from Madenjian et al. (2006).

The bioenergetics models were run at a daily time step for one year beginning on 1 January. Estimates of length-at-age and mass-length relationships for whitefish (Isaac, 2010) were used to assign start and end masses for each year class (Table 1). Daily model temperature was based on linear interpolation between mean observed bottom water temperatures of $3.9^{\circ} \mathrm{C}$ in May, $7.2^{\circ} \mathrm{C}$ in August and $6.6^{\circ} \mathrm{C}$ in October (Isaac, 2010), and a compiled estimate of $2.5^{\circ} \mathrm{C}$ in January (Assel, Croley \& Schneider, 1994). Model inputs for ageat-maturity and spawning date were taken from Isaac (2010), and percentage mass loss to spawning was taken from Madenjian et al. (2006) (Table 1). Spring (MayJune), summer (July-August) and autumn (SeptemberNovember) diet proportions were taken from Gamble et al. (2011b), and winter (December-April) diet proportions were obtained during the present study (Table 2).

Table 1 Model inputs for lake whitefish start and end weights, age-at-maturity, spawning date and percentage mass loss to spawning for each age class used in the bioenergetics modelling. Per cent mass loss due to spawning was taken from Madenjian et al. (2006). All other inputs were taken from Isaac (2010)

\begin{tabular}{lrrll}
\hline $\begin{array}{l}\text { Age } \\
\text { class }\end{array}$ & $\begin{array}{l}\text { Start } \\
\text { mass }(\mathrm{g})\end{array}$ & $\begin{array}{l}\text { End } \\
\text { mass }(\mathrm{g})\end{array}$ & $\begin{array}{l}\text { Spawning } \\
\text { date }\end{array}$ & $\begin{array}{l}\text { \% Mass loss } \\
\text { to spawning }\end{array}$ \\
\hline 2 & 90.9 & 158.7 & $\mathrm{n} / \mathrm{a}$ & 0.0 \\
3 & 158.7 & 248.5 & $\mathrm{n} / \mathrm{a}$ & 0.0 \\
4 & 248.5 & 360.2 & $\mathrm{n} / \mathrm{a}$ & 0.0 \\
5 & 360.2 & 493.1 & November 1 & 5.2 \\
6 & 493.1 & 646.0 & November 1 & 5.2 \\
7 & 646.0 & 817.0 & November 1 & 5.2 \\
8 & 817.0 & 1004.0 & November 1 & 5.2 \\
9 & 1004.0 & 1111.5 & November 1 & 5.2 \\
\hline
\end{tabular}

(C) 2014 John Wiley \& Sons Ltd, Freshwater Biology, 59, 1197-1212 
Table 2 Diet proportions by wet mass for whitefish used to estimate annual consumption. Data were taken from Gamble et al. (2011b), except for diet composition of whitefish in the months of December-April which were derived from the present study. Data for February were linearly interpolated between December and March. Energy density is in $\mathrm{kJ} \mathrm{g}^{-1}$ wet. Other category for whitefish includes clams and leeches

\begin{tabular}{llllll}
\hline Month & Mysis & Diporeia & $\begin{array}{l}\text { Cisco } \\
\text { eggs }\end{array}$ & Chironomids & Other \\
\hline May-June & 0.87 & 0.13 & 0.00 & 0.00 & 0.00 \\
July-August & 0.47 & 0.43 & 0.00 & 0.00 & 0.11 \\
$\begin{array}{l}\text { September- } \\
\quad 0.69\end{array}$ & 0.30 & 0.00 & 0.01 & 0.00 \\
$\quad$ November & & & & & \\
December & 0.00 & 0.00 & 0.99 & 0.00 & 0.01 \\
January & 0.00 & 0.00 & 1.00 & 0.00 & 0.00 \\
$\begin{array}{l}\text { March } \\
\text { April }\end{array}$ & 0.00 & 0.29 & 0.25 & 0.32 & 0.14 \\
Energy & 0.00 & 0.00 & 0.09 & 0.38 & 0.53 \\
$\quad$ density & $3.537^{*}$ & $4.386^{*}$ & $10.312^{\ddagger}$ & $2.427^{+}$ & 3.064 \\
\hline
\end{tabular}

*Gardner et al. (1985).

tCummins \& Wuycheck (1971).

$\ddagger$ Present study.

Daily consumption estimates of each prey type were derived for an individual fish in each whitefish year class (ages two to nine). The numerical density of each year class was estimated by apportioning whitefish total densities (fish ha ${ }^{-1}$ ) to year classes based on an agelength key and length-frequency distributions (Isaac, 2010). Total densities for whitefish were taken from the annual spring bottom trawl survey as described above. The annual consumption estimate for each individual for each year class was multiplied by year class density and then summed across year classes to estimate annual consumption on a per hectare basis. These estimates were then multiplied by 45760 ha to estimate overall whitefish annual and winter consumption for the study region. We compared annual and winter consumption estimates with the sum of estimates of standing stock and annual production for both Mysis and Diporeia, the standing stock of cisco eggs and their energetic equivalents. Production was estimated by multiplying standing stock by annual production to biomass ratios $(\mathrm{P} / \mathrm{B})$ for Mysis (3.21; Isaac, 2010) and Diporeia (0.80; Auer, Cannon \& Auer, 2009).

Because we found cisco eggs to be an important part of whitefish diet, we ran an additional bioenergetics simulation to evaluate the extent to which an individual whitefish would have to compensate for the absence of the eggs (e.g. if the cisco stock collapsed) by feeding on other prey to achieve the same growth. To do this, we simulated whitefish growth using starting and ending masses for an age-six individual (Table 1) and altered their dietary composition. We extended the per cent diet composition for September-November until March (Table 1) and then evenly allocated the per cent of the diet composition that was cisco eggs in March and April to the remaining (consumed) diet items in each month. We ran a simulation for one year, with all other inputs and parameters the same as described above, and estimated the per cent increase in biomass consumption.

\section{Stable isotope analyses}

We sampled the fish community between Cornucopia and Sand Island during November 2009 and April-May 2010 using bottom trawl and midwater trawl gear (Fig. 1) to collect tissue samples for stable isotope analyses. This area was chosen because (i) it was known to support a high density of spawning cisco (Yule et al., 2009), (ii) the stomach samples for whitefish were available through the winter from a commercial fishing operation and (iii) past sampling showed the fish assemblage in the area was species rich (USGS, unpubl. data). We attempted to collect 10 individuals of smaller-bodied fish species and 10 juvenile and 10 adults of larger-bodied species. Small-bodied species included the following: rainbow smelt, ninespine stickleback (Pungitius pungitius), slimy sculpin (Cottus cognatus) and spoonhead sculpin (Cottus recei). Larger-bodied species included the following: shortjaw cisco (Coregonus zenithicus), cisco, bloater (Coregonus hoyi) and whitefish. Individuals were frozen in the field and kept frozen until laboratory processing. In the laboratory, individuals were thawed and muscle and liver samples were collected from whitefish. Perga \& Gerdeaux (2005) demonstrated that, in European whitefish (C. lavaretus), tissues with more rapid turnover, such as liver, reflect the recent diet more closely than does muscle during periods of slow growth. Muscle samples from other members of the fish assemblage were also collected, as were cisco ovaries from autumn 2009 spawners in the study region and cisco eggs from whitefish stomachs, when collected in sufficient numbers throughout winter. Mysis and Diporeia samples for stable isotope analyses were collected in the autumn and spring at a 73-m deep station between Cornucopia and Sand Island (Fig. 1). Additionally, Diporeia samples were collected at 25- and 108-m-deep stations in the same vicinity during spring. Macroinvertebrate samples were frozen until laboratory processing.

For stable isotope analyses, samples ( $1-3 \mathrm{~g}$ wet) were dried at $65{ }^{\circ} \mathrm{C}$ for $48 \mathrm{hr}$ in aluminium boats and homogenised with a mortar and pestle. For each dried sample, an aliquot of $0.9-1.1 \mathrm{mg}$, measured to the nearest 
$0.001 \mathrm{mg}$, was placed in a tin capsule. Samples were analysed for $\delta^{15} \mathrm{~N}, \delta^{13} \mathrm{C}, \% \mathrm{~N}$ and \% C using a Costech ECS4010 elemental analyser (Costech Analytical Technologies, Inc, Valencia, CA, U.S.A.) coupled with a DELTA $_{\text {plus }}$ XP isotope ratio mass spectrometer (Thermo Scientific, Bremen, Germany) at the University of New Hampshire Stable Isotope Laboratory. Carbon and nitrogen isotope data are reported in $\delta$ units $(\%)$ according to $\left(\left[R_{\text {sample }} / R_{\text {standard }}\right]-1\right) \times 1000$, where $\mathrm{R}$ is the ratio ${ }^{13} \mathrm{C} /{ }^{12} \mathrm{C}$ or ${ }^{15} \mathrm{~N} /{ }^{14} \mathrm{~N}$ (Peterson \& Fry, 1987), and the standard was Vienna Pee Dee belemnite (VPDB) for carbon and atmospheric $\mathrm{N}_{2}$ for nitrogen. The $\delta^{15} \mathrm{~N}$ and $\delta^{13} \mathrm{C}$ values were normalised on the VPDB and AIR scales with IAEA CH6 $(-10.4 \%)$, CH7 $\left(-31.8 \%{ }^{\circ}\right)$, N1 $(0.4 \%)$ and N2 $(20.3 \%$ ).

Commercially available reference materials were used to confirm the accuracy and precision of stable isotope analyses. Means $( \pm \mathrm{SD})$ were $9.2 \pm 0.1 \%$ for $\delta^{15} \mathrm{~N}$ and $-25.4 \pm 0.2 \%$ for $\delta^{13} \mathrm{C}$ for bolete $(n=59$; true values $=9.2$ and $-25.4 \%$ for $\delta^{15} \mathrm{~N}$ and $\delta^{13} \mathrm{C}$, respectively), and $0.6 \pm 0.1 \%$ for $\delta^{15} \mathrm{~N}$ and $-27.0 \pm 0.1 \%$ for $\delta^{13} \mathrm{C}$ for NIST15 $\left(n=69\right.$; true values $=0.7$ and $-27.0 \%$ for $\delta^{15} \mathrm{~N}$ and $\delta^{13} \mathrm{C}$, respectively).

We estimated per cent lipid (L) of whitefish samples using the equation $\mathrm{L}=93 /\left(1+(0.246 \cdot \mathrm{C}: \mathrm{N}-0.775)^{-1}\right)$, where $\mathrm{C}: \mathrm{N}$ is the molar $\mathrm{C}: \mathrm{N}$ ratio (McConnaughy \& McRoy, 1979). Molar C : N was derived by converting mass-based $\mathrm{C}: \mathrm{N}$ measurements from stable isotope analyses to molar. Fagan et al. (2010) concluded that arithmetic estimation of lipids from $\mathrm{C}: \mathrm{N}$ data was not reliable. In contrast, other studies have found highly significant statistical relationships between $\mathrm{C}: \mathrm{N}$ and measured lipid content (e.g. Kiljunen et al., 2006; Logan et al., 2008; Abrantes et al., 2012). To illustrate seasonal changes in whitefish tissue composition, we present both per cent lipid, calculated according to McConnaughy \& McRoy (1979), and C : N ratios. To examine some isotopic shifts more closely, we calculated lipid-corrected $\delta^{13} \mathrm{C}$ values for muscle, according to Kiljunen et al. (2006), and liver, according to Logan et al. (2008).

Circular statistics (Batschelet, 1981) were used to test whether the stable isotope values of the fish assemblage shifted in a manner consistent with a diet of cisco eggs over the winter. Following Schmidt et al. (2007), we used average $\delta^{13} \mathrm{C}$ and $\delta^{15} \mathrm{~N}$ values to represent the food-web coordinates $(x, y)$ for each fish species and life-stage (adult or juvenile, when available) in autumn and spring. We estimated the magnitude $(r)$ and direction (or angle) of change $(\theta)$ in food-web space between the two time periods for each species and then tested for directional change among species using Rayleigh's test for circular uniformity (Schmidt et al., 2007).

\section{Results}

\section{Cisco eggs and macroinvertebrate availability}

The relationship between ovary mass (range $=12.8$ $124.4 \mathrm{~g}$ ) and female mass (range $=124-764 \mathrm{~g}$ ) was statistically significant $\left(F=308, P<0.0001, r^{2}=0.89, n=41\right)$ and described by $Y=0.148 \cdot X-6.901$, where $Y$ is ovary mass $(\mathrm{g})$ and $X$ is female mass $(\mathrm{g})$. Based on this fecundity-mass relationship, the 2006 mean $( \pm$ SE) adult cisco density $\left(366 \pm 24 \mathrm{ha}^{-1}\right)$ in the study area, sex ratio $(66 \%$ female) and size structure of the spawning cisco population in the western arm of Lake Superior (Yule et al., 2009), we estimate that cisco deposited $11.5 \pm 0.8 \mathrm{~kg} \mathrm{ha}^{-1}$ of eggs, giving a total of $526 \pm 34$ metric tons $(\mathrm{mt})$ in the whole study area during 2006 (Fig. 2). Energy density of cisco ovaries averaged ( $\pm \mathrm{SE}$ ) $10.3 \pm 0.2 \mathrm{~kJ} \mathrm{~g}^{-1}$ wet mass ( $n=10$ fish). Given the biomass of cisco eggs and their mean energy density, the total energy value of cisco eggs deposited along the Wisconsin south shore of Lake Superior was $5421 \pm 355$ gigajoules (GJ; Fig. 2).

Other prey available to benthic fish over winter, as measured by the estimated standing stock of the macroinvertebrates Mysis and Diporeia, was $359 \pm 161 \mathrm{mt}$ and $1684 \pm 472 \mathrm{mt}$, respectively (Fig. 2). Cisco eggs therefore represented $20 \%$ of available prey by biomass. On an energetic basis, however, cisco eggs represented 39\% of available prey (Fig. 2) because of their higher energy density (Table 2).

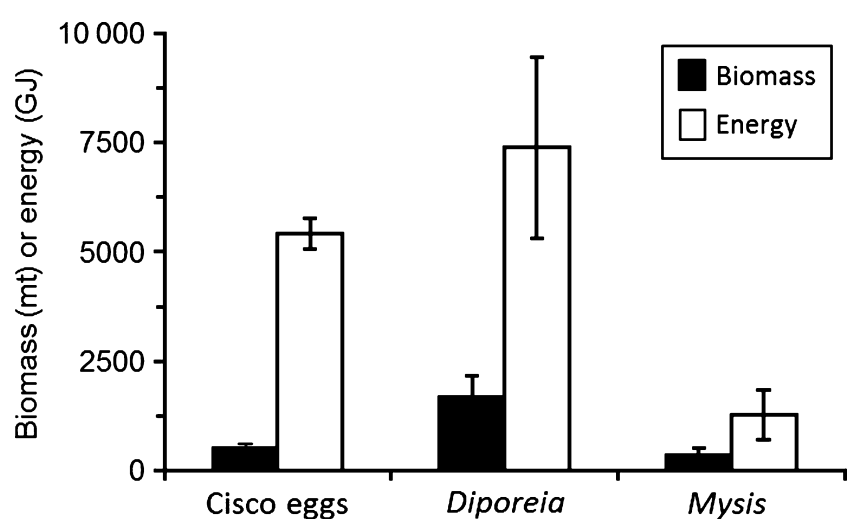

Fig. 2 Average ( \pm SE) biomass (solid bars) and energy (open bars) of major benthic prey resources in the Wisconsin south shore region of Lake Superior over the winter (cisco eggs) and throughout the year (Diporeia and Mysis).

(C) 2014 John Wiley \& Sons Ltd, Freshwater Biology, 59, 1197-1212 
Table 3 Average $( \pm$ SE) total prey biomass and cisco egg biomass found in whitefish stomachs collected between December 2009 and April 2010 and in December 2011. Total lengths are reported as average values $( \pm \mathrm{SE})$, and empty stomachs are per cent of number of stomachs examined

\begin{tabular}{lllcrr}
\hline Date & $\begin{array}{l}\text { No. } \\
\text { stomachs }\end{array}$ & $\begin{array}{l}\text { Total length } \\
(\mathrm{mm})\end{array}$ & $\begin{array}{l}\text { \% Empty } \\
\text { Stomachs }\end{array}$ & $\begin{array}{l}\text { Total prey } \\
\text { biomass }(\mathrm{g})\end{array}$ & \multicolumn{1}{l}{$\begin{array}{l}\text { Cisco egg } \\
\text { biomass }(\mathrm{g})\end{array}$} \\
\hline December 2009 & 5 & $451 \pm 12.2$ & 0 & $22.1 \pm 3.65$ & $22.1 \pm 3.65$ \\
January 2010 & 6 & $450 \pm 6.6$ & 0 & $13.3 \pm 3.26$ & $13.3 \pm 3.26$ \\
March 2010 & 20 & $460 \pm 3.0$ & 75 & $0.4 \pm 0.19$ & $0.1 \pm 0.11$ \\
April 2010 & 15 & $459 \pm 4.2$ & 53 & $0.1 \pm 0.07$ & $<0.1 \pm 0.02$ \\
December 2011 & 20 & $436 \pm 4.2$ & 0 & $24.7 \pm 1.78$ & $23.9 \pm 1.82$ \\
\hline
\end{tabular}
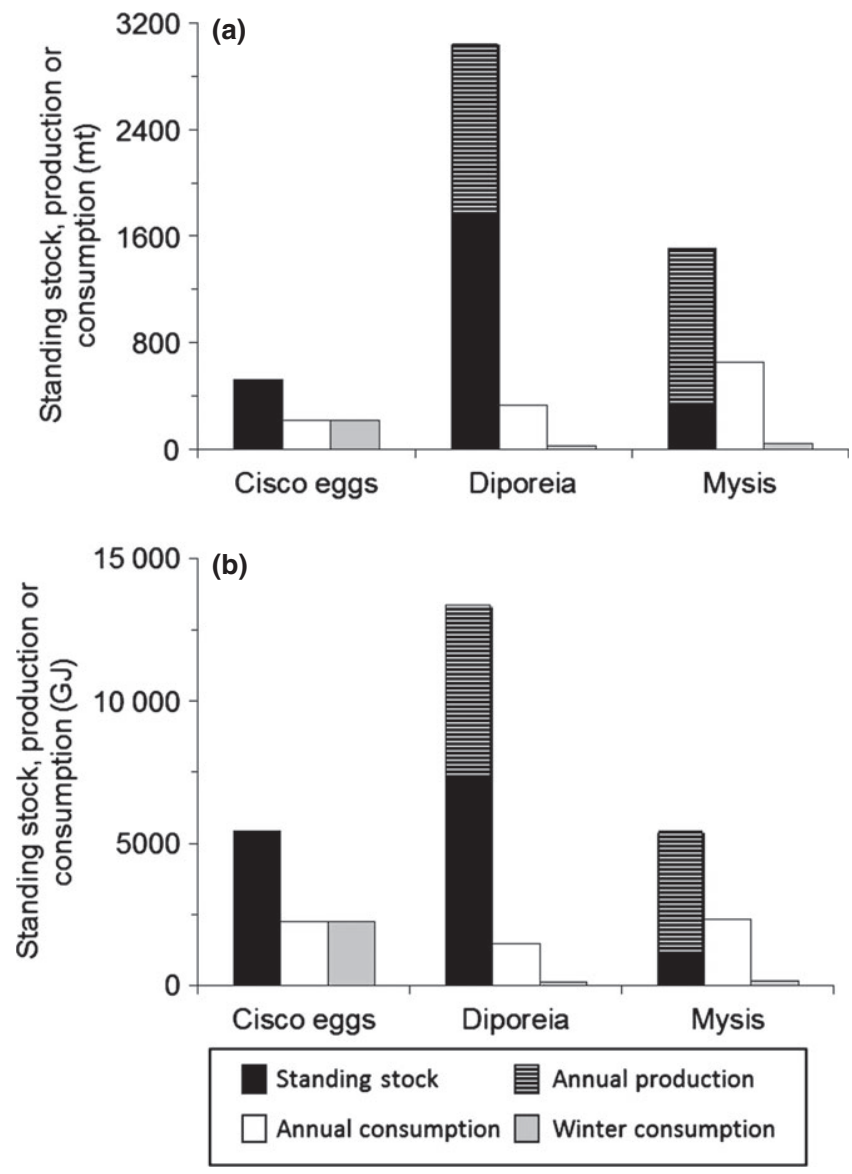

Fig. 3 (a) Standing stock of Mysis, Diporeia, and cisco eggs (black bars), annual production of Mysis and Diporeia (horizontal striped bars), and annual (open bars) and winter (grey bars) consumption demand by lake whitefish for the three primary prey types on the Wisconsin south shore region of Lake Superior. (b) Same as (a) except on an energy basis. Standing stock estimate of cisco eggs is taken from 2006. Standing stock and annual production estimates of macroinvertebrates are taken from spring, summer and autumn collections in 2005.

cisco eggs represented $79 \%$ of the energy consumed by whitefish (Fig. 3b).

To evaluate the importance of cisco eggs for whitefish annual energy intake, cisco eggs were modelled as 'dropped from the diet'. The estimated annual consumption of prey biomass by an age-six whitefish would need 
to increase $32 \%$ to compensate for the absence of eggs to grow at the observed rate.

\section{Stable isotope analyses and lipid estimates}

Stable isotope values of cisco eggs collected during November were significantly different from values for Mysis and Diporeia. Mean November values $( \pm \mathrm{SE})$ were $-28.8 \pm 0.1 \%$ for $\delta^{13} \mathrm{C}$ and $6.5 \pm 0.1 \%$ for $\delta^{15} \mathrm{~N}$ for cisco eggs compared to -27.4 and $4.0 \%$ for Mysis and -26.9 and $4.4 \%$ for Diporeia (Table 4). Because whitefish $\delta^{15} \mathrm{~N}$ values for muscle and liver tissue in November $(6.8 \pm 0.1$ and $5.9 \pm 0.2 \%$, respectively) were similar to cisco eggs and appeared greater than Mysis and Diporeia, we expected a shift in whitefish stable isotope values to higher $\delta^{15} \mathrm{~N}$ values through the winter if cisco eggs were a major component of their diet.

Whitefish muscle $\delta^{15} \mathrm{~N}$ values increased significantly from autumn to spring $\left(F_{0.05(2), 5,47}=6.8, P<0.0001\right.$, $\left.r^{2}=0.42\right)$ with a maximum mean difference of $0.9 \%$ between the months of November and March (Fig. 4a). Liver $\delta^{15} \mathrm{~N}$ values also increased significantly from autumn to spring $\left(F_{0.05(2)}, 5, \quad 48=43.0, \quad P<0.0001\right.$, $r^{2}=0.82$ ), with a maximum mean difference of $2.2 \%$ between the months of November and March (Fig. 4b). The $\delta^{13} \mathrm{C}$ values for muscle and liver both decreased over winter $\left(F_{0.05(2), 5,47}=3.3, P=0.0118, r^{2}=0.26\right.$ for muscle; $F_{0.05(2), 5,48}=4.3, P<0.0028, r^{2}=0.31$ for liver) with both tissues showing significant differences between November and March (Fig. 4).
Per cent lipid estimates of whitefish liver changed significantly over the winter months $\left(F_{0.05(2), 5,48}=15.2\right.$, $\left.P<0.0001, r^{2}=0.61\right)$. Estimates $( \pm \mathrm{SE})$ almost doubled between November $(26 \pm 0.7 \%)$ and January $(48 \pm 2.3 \%)$, with a peak in March $(49 \pm 2.5 \%$; Fig. 5). These trends were mirrored by average liver $\mathrm{C}: \mathrm{N}$ ratios $( \pm \mathrm{SD})$, which increased from $4.8 \pm 0.2$ in November to $8.0 \pm 1.5$ in March. Whitefish muscle lipid content also changed significantly over the winter months $\left(F_{0.05}\right.$ (2) $\left.5,48=4.1, P=0.0034, r^{2}=0.30\right)$, with a steady increase between November and March (Fig. 5). Mean muscle $\mathrm{C}: \mathrm{N}$ also increased from $3.9 \pm 0.3$ in November to $4.8 \pm$ in March.

Lipid-corrected $\delta^{13} \mathrm{C}$ values for whitefish liver and muscle tissues indicated that seasonal decreases in liver and muscle $\delta^{13} \mathrm{C}$ were driven by those increases in lipid content. Mean uncorrected liver $\delta^{13} \mathrm{C}$ declined (November to March) by $2.1 \%$ (from -24.5 to $-26.6 \%$; Fig. 4 b), whereas lipid-corrected values decreased by only $0.4 \%$ o (from -22.8 to $-23.2 \% ; t=1.4, P=0.20$, d.f. $=16$ ). Mean uncorrected muscle $\delta^{13} \mathrm{C}$ declined (November to March) by $1.3 \%$ (from -24.4 to $-25.7 \%$ Fig. $4 a$ ), whereas average lipid-corrected values decreased by only $0.3 \%$ (from -22.8 to $-23.1 \%$; $t=1.2, P=0.24$, d.f. $=16)$.

The $\delta^{13} \mathrm{C}-\delta^{15} \mathrm{~N}$ biplot of muscle tissue samples from fish assemblage members between autumn 2009 and spring 2010 is consistent with a diet of cisco eggs over the winter (Fig. 6a). All fish species showed a similar trajectory through food-web space (average $\theta \pm$ circular

Table $4 \delta^{13} \mathrm{C}$ and $\delta^{15} \mathrm{~N}(\%)$ for cisco eggs, Mysis, and Diporeia between autumn 2009 and spring 2010. When more than one sample was available, the average $( \pm \mathrm{SE})$ is reported. Sample sizes are shown in parentheses. Cisco eggs were taken from spawning cisco (November) or from lake whitefish stomachs (remaining time periods). Station depths from which macroinvertebrate samples were collected are indicated (parenthetically) in left column

\begin{tabular}{|c|c|c|c|c|c|c|}
\hline Prey Item & November & December & January & March & April & May \\
\hline \multicolumn{7}{|l|}{ Cisco eggs } \\
\hline$\delta^{13} \mathrm{C}$ & $-28.8 \pm 0.1(9)$ & $-28.4(1)$ & $-29.0 \pm 0.06(2)$ & $-28.5(1)$ & & $-28.0(1)$ \\
\hline \multicolumn{7}{|l|}{ Mysis } \\
\hline$(73 \mathrm{~m}) \delta^{13} \mathrm{C}$ & $-27.4^{\mathrm{A}}(1)$ & & & & $-28.3(1)$ & \\
\hline$(73 \mathrm{~m}) \delta^{15} \mathrm{~N}$ & $4.0^{\mathrm{B}}(1)$ & & & & $7.1(1)$ & \\
\hline$(25 \mathrm{~m}) \delta^{15} \mathrm{~N}$ & & & & & $4.3(1)$ & \\
\hline$(73 \mathrm{~m}) \delta^{13} \mathrm{C}$ & $-26.9^{C}(1)$ & & & & $-27.1(1)$ & \\
\hline$(73 \mathrm{~m}) \delta^{15} \mathrm{~N}$ & $4.4^{\mathrm{D}}(1)$ & & & & $6.0(1)$ & \\
\hline$(108 \mathrm{~m}) \delta^{13} \mathrm{C}$ & & & & & $-27.3(1)$ & \\
\hline$(108 \mathrm{~m}){ }^{15} \mathrm{~N}$ & & & & & $7.3(1)$ & \\
\hline
\end{tabular}

\footnotetext{
${ }^{\text {A }}$ Significantly different from cisco eggs in November (one-sample $t$-test, $t=9.9$, d.f. $=8, P<0.0001$ ).

${ }^{\mathrm{B}}$ Significantly different from cisco eggs in November (one-sample $t$-test, $t=20.7$, d.f. $=8, P<0.0001$ ).

${ }^{C}$ Significantly different from cisco eggs in November (one-sample $t$-test, $t=13.4$, d.f. $=8, P<0.0001$ ).

${ }^{D}$ Significantly different from cisco eggs in November (one-sample $t$-test, $t=17.1$, d.f. $=8, P<0.0001$ ).
} 

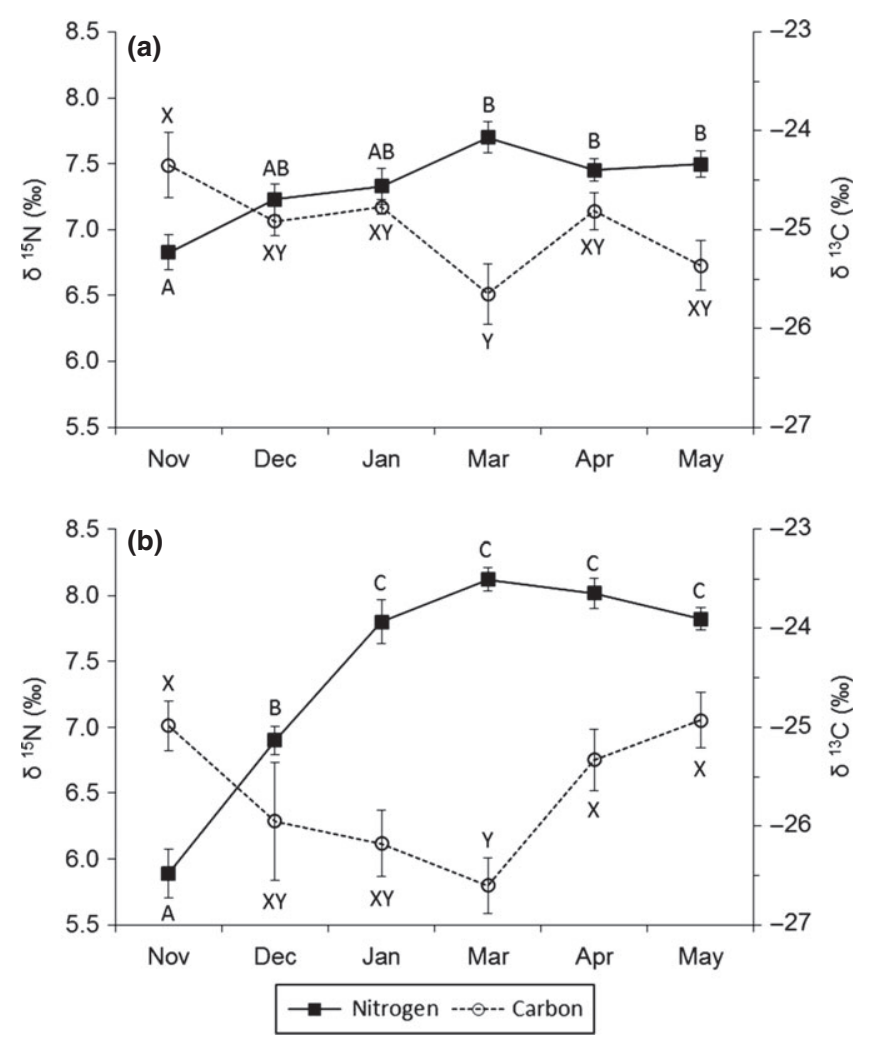

Fig. 4 Mean $( \pm \mathrm{SE}) \delta^{13} \mathrm{C}$ (open circles; uncorrected for lipids) and $\delta^{15} \mathrm{~N}$ (closed squares) trajectories for (a) muscle and (b) liver samples of lake whitefish from November 2009 to May 2010. Estimates labelled with the same letter indicate no significant difference among months for each tissue type and isotope (Tukey's honestly significant difference test; $\alpha=0.05$ ). ABC lettering refers to $\delta^{15} \mathrm{~N}$ tests and $\mathrm{XY}$ lettering refers to $\delta^{13} \mathrm{C}$.

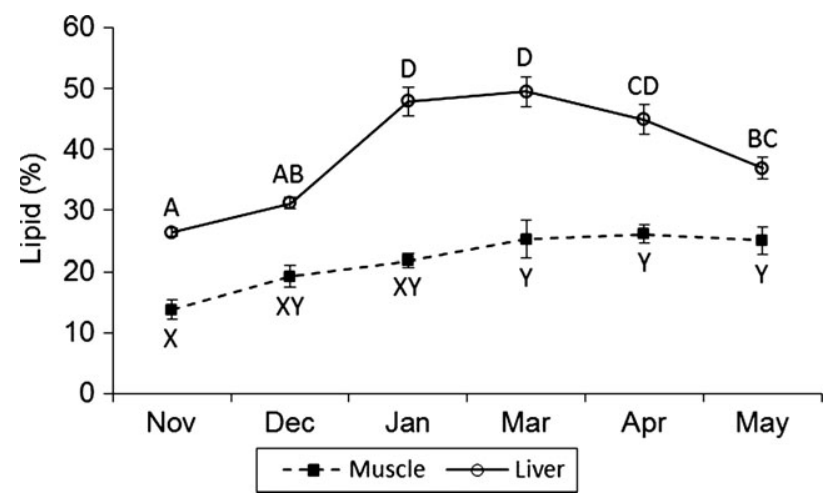

Fig. 5 Mean $( \pm S E)$ per cent lipid estimates for liver (open circles) and muscle (closed squares) samples of lake whitefish from November 2009 to May 2010. Estimates labelled with the same letter indicate no significant difference among months for each tissue type (Tukey's honestly significant difference test; $\alpha=0.05$ ). ABCD lettering refers to liver tests and $X Y$ lettering refers to muscle tests.

$\mathrm{SD}=320 \pm 13^{\circ}, \quad$ range of $\theta=296-340^{\circ}, \quad$ Rayleigh's $Z=9.5, P<0.0001$; Fig. $6 \mathrm{~b}$ ). However, the changes cannot unequivocally be attributed to a diet dominated by cisco eggs because the isotopic values of Mysis and Diporeia also shifted closer to the value of cisco eggs sometime between autumn and spring (Table 4). The $\delta^{15} \mathrm{~N}$ values for Mysis and Diporeia samples, collected at the same 73-m-depth station as the previous autumn, increased by 3.1 and $2.0 \%$, respectively. Additionally, $\delta^{15} \mathrm{~N}$ values for Diporeia in April showed a positive trend with depth, increasing from $4.3 \%$ at $25-\mathrm{m}$ depth to $7.3 \%$ at $108-\mathrm{m}$ depth (Table 4 ), consistent with the findings of Sierszen, Peterson \& Scharold (2006). The $\delta^{13} \mathrm{C}$ values were within the range of variation expected for these depths (Sierszen et al., 2006).

\section{Discussion}

Awareness of the importance of habitat coupling has grown over the last two decades (Polis et al., 1997; Schindler \& Scheuerell, 2002; Loreau, Mouquet \& Holt, 2003). Our findings indicate that cisco provide a substantial spatial resource subsidy from offshore pelagic to nearshore benthic habitats in the Wisconsin south shore region of Lake Superior. On a biomass basis, cisco eggs represented $16 \%$ of annual and $54 \%$ of winter (December to April) consumption by whitefish. On an energetic basis, cisco eggs represented $34 \%$ of annual and $79 \%$ of winter consumption. On an annual time scale, only Mysis represented a greater source of energy for whitefish in our study region, at $36 \%$. The availability of cisco eggs, and their high energy density compared to other available prey, may explain their extensive use by whitefish during the winter. Furthermore, the reduced cost of foraging on eggs versus mobile prey probably provides additional energetic gain through reduced foraging costs. Diet and bioenergetics simulations were corroborated by significant isotopic shifts in whitefish livers during the winter period. Lipid-corrected liver and muscle $\delta^{13} \mathrm{C}$ showed small seasonal changes, indicating that lipid accumulation drove the patterns in whitefish isotope data. Although Mysis and Diporeia developed isotope values similar to those of cisco eggs over winter, the small energetic demand predicted for those macroinvertebrates relative to that predicted for eggs, based on winter diet analyses and bioenergetics modelling, points to egg consumption as the cause for the seasonal isotopic shifts in whitefish tissues. Taken together, our results indicate a strong linkage between offshore secondary production and the dominant nearshore benthivore, whitefish, via the dominant offshore planktivore, cisco.

Cisco eggs are clearly of major importance for whitefish in our study region. To our knowledge, there is no previous documentation of this or other similar findings 

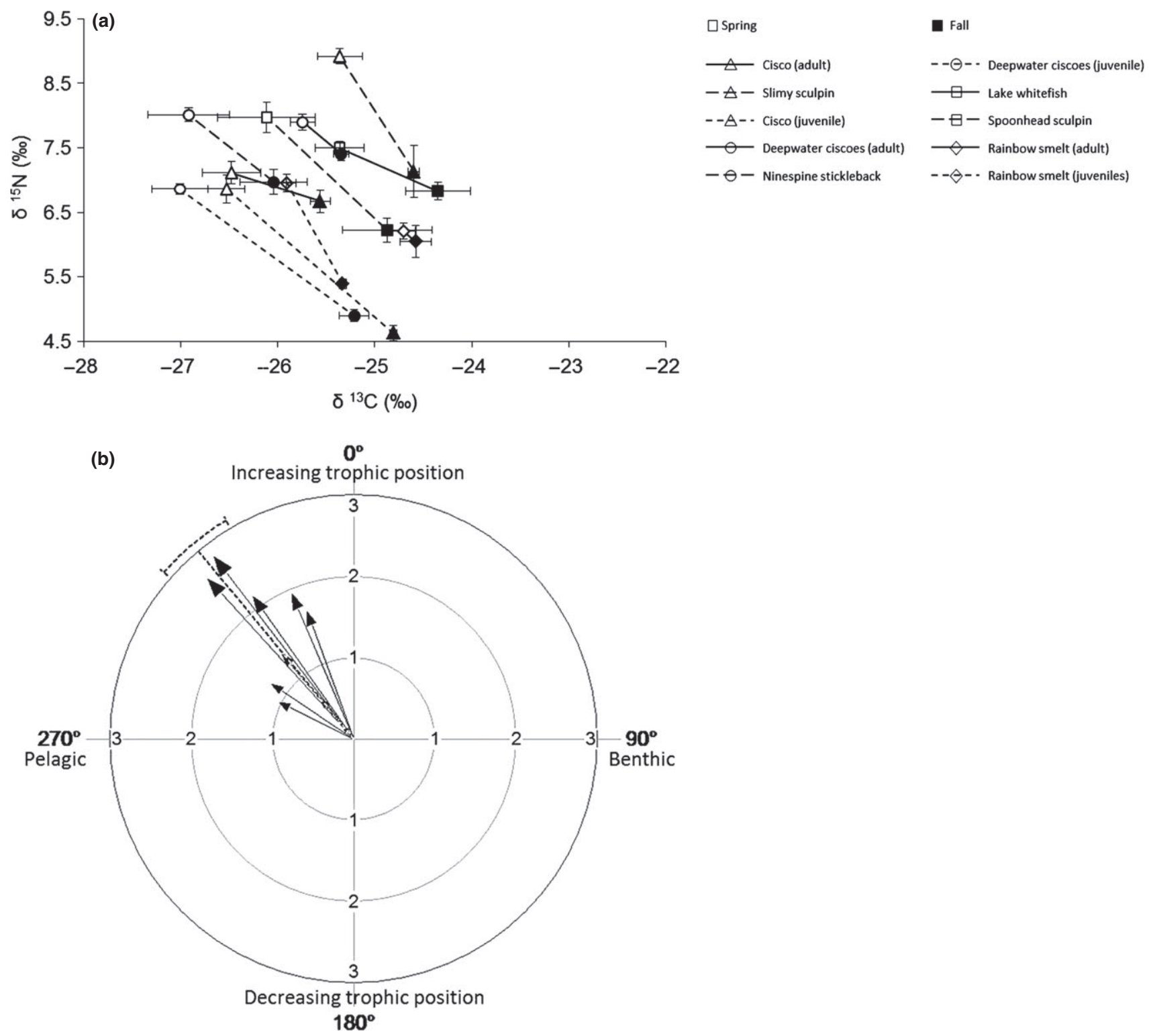

Fig. 6 (a) Biplot of average $( \pm \mathrm{SE}) \delta^{13} \mathrm{C}$ (uncorrected for lipids) and $\delta^{15} \mathrm{~N}$ values of muscle samples taken from fish species captured in the Wisconsin south shore region of Lake Superior in autumn 2009 (solid symbols) and spring 2010 (open symbols): adult (circles with solid lines, $N=13$ for autumn, $N=18$ for spring) and juvenile (circles with short-dashed lines, $N=6$ for autumn, $N=20$ for spring) 'deepwater ciscoes' (i.e. bloater and shortjaw cisco combined); adult (triangles with solid lines, $N=10$ for autumn, $N=13$ for spring) and juvenile (triangles with short-dashed lines, $N=9$ for autumn, $N=10$ for spring) cisco; adult (diamonds with solid line, $N=10$ for autumn, $N=10$ for spring) and juvenile (diamonds with short-dashed lines, $N=10$ for autumn, $N=12$ for spring) rainbow smelt; adult lake whitefish (squares with solid lines, $N=8$ for autumn, $N=10$ for spring); ninespine stickleback (circles with long-dashed lines, $N=7$ for autumn, $N=10$ for spring); spoonhead sculpin (squares with long-dashed lines, $N=10$ for autumn, $N=4$ for spring); and slimy sculpin (triangles with long-dashed lines, $N=3$ for autumn, $N=11$ for spring). (b) Arrow diagram for directionality (angle of change $\theta$ ) for each fish species and life-stage in Panel (a). Each arrow represents the direction and magnitude of change for a single species or life-stage between autumn (origin) and spring (tip of arrow). The length of the arrow represents the magnitude of change for that species. The mean angle of change $(\mu)$ among all species and life-stages is represented by the straight dashed line, and its $95 \%$ confidence interval is represented by the curved dashed line on the rim.

in the Laurentian Great Lakes. Only two other published studies in the last 50 years have found fish eggs to constitute more than $3 \%$ of the stomach contents of whitefish. Lumb et al. (2007) found unidentified fish eggs to represent $20 \%$ of stomach contents (by biomass) for whitefish captured in the autumn and 13\% in the spring in Lake Erie. Herbst, Marsden \& Lantry (2013) found fish eggs to compose $42 \%$ of the diet (by biomass) for whitefish $<800 \mathrm{~g}$ in spring in Lake Champlain. It appears that a paucity of winter diet information is at 
Table 5 List of lake whitefish diet studies from North America over the last 50 years and the reported seasons from which diet samples were collected. List excludes studies on larval diets

\begin{tabular}{|c|c|c|c|c|c|}
\hline \multirow[b]{2}{*}{ Study } & \multirow[b]{2}{*}{ Lake(s) } & \multicolumn{4}{|c|}{ Diet sampling? } \\
\hline & & Spring & Summer & Fall & Winter \\
\hline Anderson \& Smith (1971) & Superior & $\mathrm{Y}$ & $\mathrm{Y}$ & $\mathrm{Y}$ & $\mathrm{Y}$ \\
\hline Ihssen et al., 1981; & $\begin{array}{l}\text { Ontario, Huron, } \\
\text { Simcoe, Opeongo }\end{array}$ & $\mathrm{N}$ & Y & $\mathrm{N}$ & $\mathrm{N}$ \\
\hline Tohtz (1993) & Flathead & $\mathrm{Y}$ & $\mathrm{Y}$ & $\mathrm{Y}$ & $\mathrm{Y}$ \\
\hline Hoyle et al. (1999) & Ontario & $\mathrm{U}$ & $\mathrm{U}$ & $\mathrm{U}$ & $\mathrm{U}$ \\
\hline Pothoven et al. (2001) & Michigan & $\mathrm{Y}$ & $\mathrm{Y}$ & $\mathrm{Y}$ & $\mathrm{N}$ \\
\hline Owens \& Dittman (2003) & Ontario & $\mathrm{Y}$ & $\mathrm{Y}$ & $\mathrm{Y}$ & $\mathrm{N}$ \\
\hline $\begin{array}{l}\text { Stafford, Hansen \& } \\
\text { Stanford (2004) }\end{array}$ & Flathead & $\mathrm{Y}$ & $\mathrm{N}$ & $\mathrm{Y}$ & $\mathrm{N}$ \\
\hline Pothoven (2005) & Michigan & $\mathrm{Y}$ & $\mathrm{Y}$ & $\mathrm{Y}$ & $\mathrm{N}$ \\
\hline Hoyle (2005) & Ontario & $\mathrm{N}$ & $\mathrm{Y}$ & $\mathrm{N}$ & $\mathrm{N}$ \\
\hline Madenjian et al. (2006) & Michigan & $\mathrm{Y}$ & $\mathrm{Y}$ & $\mathrm{Y}$ & $\mathrm{N}$ \\
\hline Pothoven \& Nalepa (2006) & Huron & $\mathrm{Y}$ & $\mathrm{Y}$ & $\mathrm{N}$ & $\mathrm{N}$ \\
\hline Lumb et al. (2007) & Erie, Ontario & $\mathrm{Y}$ & $\mathrm{Y}$ & Y & $\mathrm{N}$ \\
\hline $\begin{array}{l}\text { Nalepa, Pothoven \& } \\
\text { Fanslow (2009) }\end{array}$ & Huron & $\mathrm{Y}$ & Y & $\mathrm{N}$ & $\mathrm{N}$ \\
\hline $\begin{array}{l}\text { Rennie, Sprules \& } \\
\text { Johnson (2009) }\end{array}$ & Huron & $\mathrm{Y}$ & $\mathrm{Y}$ & $\mathrm{Y}$ & $\mathrm{N}$ \\
\hline Claramunt et al. (2010) & Michigan, Superior & $\mathrm{Y}$ & $\mathrm{Y}$ & $\mathrm{N}$ & $\mathrm{N}$ \\
\hline Macpherson et al. (2010) & Huron & $\mathrm{Y}$ & $\mathrm{N}$ & $\mathrm{Y}$ & $\mathrm{N}$ \\
\hline Gamble et al. $(2011 a, b)$ & Superior & $\mathrm{Y}$ & $\mathrm{Y}$ & $\mathrm{Y}$ & $\mathrm{N}$ \\
\hline Herbst et al. (2013) & Champlain & $\mathrm{Y}$ & $\mathrm{Y}$ & $\mathrm{Y}$ & $\mathrm{Y}$ \\
\hline
\end{tabular}

$\mathrm{Y}$, yes; N, no; U, unreported. least partly responsible for these patterns (Table 5). However, the relatively intact native fish community of Lake Superior, with large populations of both cisco and whitefish, enabled us to detect this trophic linkage that may currently be weak or absent in the other Great Lakes.

Isotopic shifts in other benthic nearshore fish suggest that cisco eggs also may be an important part of their diet during the winter. However, the lack of samples over the course of the winter, together with concurrent isotopic shifts in other major prey sources (Mysis and Diporeia) between autumn and spring, makes it difficult to determine the degree to which isotopic shifts in the fish assemblage are due to a diet of cisco eggs. On the one hand, the shifts in the macroinvertebrate values are consistent with seasonal lipid accumulation that has been described for boreal invertebrates (Syvaränta \& Rautio, 2010), and in Lake Superior might be linked to winter consumption of cisco eggs. Seale \& Binkowski (1988) did not find evidence for Mysis consumption of bloater eggs from Lake Michigan in laboratory experiments, but Mysis did consume embryonic bloaters. On the other hand, seasonal oscillations of isotopic signals in aquatic biota are well known, with ${ }^{13} \mathrm{C}$-depletion and ${ }^{15} \mathrm{~N}$-enrichment during winter resulting from temporal changes in nutrient pools and subsequent uptake by primary producers and consumers (e.g. Woodland et al.,
2012). Higher in the food web, ${ }^{15} \mathrm{~N}$-enrichment during winter and other seasons has been associated with starvation over a wide range of animals including fish (e.g. Cherel et al., 2005; Colborne \& Robinson, 2013). Therefore, patterns in the fish assemblage observed, based solely on isotopic shifts between autumn and spring samples, may result from a combination of mechanisms. However, our sampling of whitefish through the winter and our multi-pronged approach (diets, bioenergetics analysis, isotopes and lipids) suggest cisco eggs are an important part of the whitefish diet in winter and, moreover, for the entire year. By sampling during winter, we uncovered an important whitefish-cisco interaction that would otherwise have been obscured. Future winter collections of fish and invertebrates will be important for assessing the potential impacts of cisco eggs and other seasonal processes on the broader nearshore community. Application of multiple natural tracers (e.g. stable isotopes and essential fatty acids) would also provide better insight.

While we are confident in the interpretation of our results, there are several caveats that may have bearing on our findings. Our winter consumption estimates are based on relatively few stomach samples $(N=66)$. Consumption of cisco eggs by whitefish, however, has been known among commercial fishermen for decades, is more prevalent when cisco spawning stocks are high 
and, unlike our findings, can be high in March and April (C. Bronte, US Fish and Wildlife Service, pers. comm.). Additionally, despite our modest sample size, whitefish diet composition was consistent across consecutive months (December 2009 and January 2010) and across years (December 2009 and 2011), when eggs were presumably most available to whitefish. Both of these anecdotal and scientific observations suggest cisco egg predation by whitefish is a real and consistent phenomenon in this part of Lake Superior. A second caveat is that our winter diet data were taken from commercially captured fish $>400 \mathrm{~mm}$. We assumed the diet of these fish to be representative of all sizes modelled (age-2+). Whitefish are known to undergo ontogenetic dietary shifts related to prey size (e.g. Pothoven \& Nalepa, 2006). However, cisco eggs range in diameter from 1.8 to $2.1 \mathrm{~mm}$ and therefore do not impose gape limitations on any whitefish age-classes. Our ability to use mixing models (Phillips \& Gregg, 2001) to quantify the nutritional contribution of cisco eggs to whitefish using isotope data was limited by the similarity in the isotopic values of macroinvertebrate and eggs in the spring. However, lipid-corrected isotope data, lipid estimates based upon $\mathrm{C}: \mathrm{N}$ ratios obtained through isotope analyses, and bioenergetic modelling provided further evidence of the seasonal importance of cisco egg consumption. A final caveat is that our Mysis and Diporeia isotopic values were based on very few samples. Sierszen et al. (2011) reported isotopic values for Mysis (2.4-4.2\% for $\delta^{15} \mathrm{~N}$ and $-26.1 \%$ for $\delta^{13} \mathrm{C}$ ) and Diporeia (1.0-3.5\% for $\delta^{15} \mathrm{~N}$ and -27.3 to $-26.8 \%$ for $\delta^{13} \mathrm{C}$ ) captured in the same depth zone $(30-80 \mathrm{~m})$ throughout Lake Superior in late summer and early autumn. Their values are similar to ours from November, suggesting consistent separation of Mysis and Diporeia isotopic values from cisco eggs at the start of winter.

Future studies may be improved by comparing benthic fish growth from areas or lakes with and without spawning cisco (e.g. Botton \& Loveland, 2011). Our whitefish diet and community isotope samples were collected from a region of Lake Superior characterised by large spawning aggregations of cisco (Selgeby, 1982; Yule et al., 2009). At this time, the relevance of our findings to the rest of Lake Superior is unknown, but more detailed spatial analyses incorporating a wider range of cisco and whitefish densities, growth and foraging would help evaluate the broader applicability of our results.

If our energy transport hypothesis is true, we would expect lower spring lipid values in the absence of cisco egg deposition, akin to the observed declines in growth and condition of whitefish in Lakes Huron, Michigan and Ontario associated with declines in Diporeia (e.g. Mohr \& Nalepa, 2005). In our simulation of the absence of cisco eggs in the diet of an age-six whitefish from December to April, the whitefish had to consume 32\% more prey biomass to realise the same growth. This suggests that feeding on cisco eggs over the winter is likely to represent a significant component of their annual diet, without which they would need to increase their foraging activity to compensate (for example, see Fig. 5 in Pothoven \& Madenjian, 2008). After spawning, fish are energy-depleted and having an adequate supply of prey is very likely to be important for their recovery and future reproductive output (e.g. Burton \& Idler, 1987). Our results suggest that the energy reserves of whitefish after spawning in the Wisconsin south shore region of Lake Superior recover over winter as a result of cisco egg availability. Further, the energy they obtain over winter may have longer-term implications for their subsequent growth and reproduction (Beauchamp, Collins \& Henderson, 2004). Our results provide an example of important processes that may be affecting whitefish during the winter, a poorly studied season (Table 5). Further studies of winter feeding and food-web interactions may shed light on these processes in Lake Superior and the other Great Lakes.

Historical fluctuations in cisco abundance probably resulted in variable deposition of eggs in nearshore areas. Coupling between offshore and nearshore habitats may have been stronger when cisco populations were much more abundant in Lake Superior (Cox \& Kitchell, 2004) and the other Great Lakes (Stockwell et al., 2009). Where cisco populations have been greatly reduced or lost, this offshore-nearshore coupling is absent; cisco have been replaced by non-native planktivorous species that spawn in spring and have short incubation periods (e.g. rainbow smelt and alewife). This altered assemblage of prey fish does not support such strong movements of energy across habitats. The extent to which extant native fish in these lakes would benefit from a rehabilitated fish assemblage that includes cisco remains unknown. These processes have not yet been clearly elucidated, partly because cisco have been examined primarily as planktivores (e.g. Link, Selgeby \& Keen, 2004; Young \& Yan, 2008) and as prey (e.g. Hrabik et al., 2006; Negus et al., 2008), but also because changes in the fish assemblage in the other Great Lakes may have suppressed or eliminated those processes. Our work demonstrates that by coupling offshore pelagic and nearshore benthic production, cisco may carry out an additional, and possibly more important, ecosystem process than simply serving as a prey fish for apex predators.

(C) 2014 John Wiley \& Sons Ltd, Freshwater Biology, 59, 1197-1212 


\section{Acknowledgments}

We would like to thank Halvorson Fisheries of Cornucopia, Wisconsin, and Eric and Martin Peterson of Bayfield, Wisconsin, for providing winter samples of lake whitefish, and the Captain and crew of the R/V Kiyi for collecting winter and spring fish and invertebrate samples in support of this work. Lori Evrard, Gary Cholwek, Laura Graf, Zeb and Zach Woiak, and Jared Myers assisted in field collections and laboratory processing. Allison Gamble and Jill Scharold kindly provided diet information and benthic invertebrate abundance and biomass data, respectively. Ellen Marsden and Chuck Madenjian provided helpful comments. This article is Contribution 1819 of the U.S. Geological Survey Great Lakes Science Center. Reference to trade names does not imply endorsement by the U.S. government.

\section{References}

Abrantes K.G., Semmens J.M., Lyle J.M. \& Nichols P.D. (2012) Normalisation models for accounting for fat content in stable isotope measurements in salmonid muscle tissue. Marine Biology, 159, 57-64.

Anderson E.D. \& Smith L.L. Jr (1971) A Synoptic Study of Food Habits of 30 Fish Species from Western Lake Superior. Technical Bulletin No. 279, Agricultural Experiment Station, University of Minnesota, St. Paul, MN.

Assel R.A., Croley T.E. II \& Schneider K. (1994) Computer visualization and long term average Great Lakes Temperatures and ice cover. Journal of Great Lakes Research, 20, 771-782.

Auer N.A., Cannon B.A. \& Auer M.T. (2009) Life history, distribution, and production of Diporeia near the Keweenaw Peninsula Lake Superior. Journal of Great Lakes Research, 35, 579-590.

Batschelet E. (1981) Circular Statistics in Ecology. Academic Press, New York, NY.

Beauchamp K.C., Collins N.C. \& Henderson B.A. (2004) Covariation of growth and maturation of lake whitefish (Coregonus clupeaformis). Journal of Great Lakes Research, 30, 451-460.

Botton M.L. \& Loveland R.E. (2011) Temporal and spatial patterns of organic carbon are linked to egg deposition by beach spawning horseshoe crabs (Limulus polyphemus). Hydrobiologia, 658, 77-85.

Brown S.B., Fitzsimons J.D., Honeyfield D.C. \& Tillitt D.E. (2005) Implications of thiamine deficiency in Great Lakes salmonines. Journal of Aquatic Animal Health, 17, 113-124.

Burton M.P. \& Idler D.R. (1987) An experimental investigation of the nonreproductive, post-mature state in winter flounder. Journal of Fish Biology, 30, 643-650.

Cherel Y., Hobson K.A., Bailleul F.R. \& Groscolas R. (2005) Nutrition, physiology, and stable isotopes: new informa- tion from fasting and molting penguins. Ecology, 86, 2881-2888.

Claramunt R.M., Muir A.M., Johnson J. \& Sutton T.M. (2010) Spatio-temporal trends in the food habits of age- 0 lake whitefish. Journal of Great Lakes Research, 36, 66-72.

Cloern J.E. (2007) Habitat connectivity and ecosystem productivity: implications from a simple model. American Naturalist, 169, E21-E33.

Colborne S.F. \& Robinson B.W. (2013) Effect of nutritional condition on variation in $\delta^{13} \mathrm{C}$ and $\delta^{15} \mathrm{~N}$ stable isotope values in pumpkinseed sunfish (Lepomis gibbosus) fed different diets. Environmental Biology of Fishes, 96, 543554.

Cox S.P. \& Kitchell J.F. (2004) The Lake Superior ecosystem, 1929-1998: simulating alternative hypotheses for lake herring recruitment failure. Bulletin of Marine Science, 74, 671-684.

Cummins K.W. \& Wuycheck J.C. (1971) Caloric equivalents for investigations in ecological energetics. Mitteilungen der Internationale Vereiningung für Theoretische und Angewandte Limnologie, 18, 1-151.

Durbin A.G., Nixon S.W. \& Oviatt C.A. (1979) Effects of the spawning migration of the alewife, Alosa pseudoharengus, on freshwater ecosystems. Ecology, 60, 8-17.

Fagan K.-A., Koops M.A., Arts M.T. \& Power M. (2010) Assessing the utility of C:N ratios for predicting lipid content in fishes. Canadian Journal of Fisheries and Aquatic Sciences, 68, 374-385.

France R.L. (1995) Differentiation between littoral and pelagic food webs in lakes using stable carbon isotopes. Limnology and Oceanography, 40, 1310-1313.

Gamble A.E., Hrabik T.R., Stockwell J.D. \& Yule D.L. (2011a) Trophic connections in Lake Superior Part I: the offshore fish community. Journal of Great Lakes Research, $37,541-549$.

Gamble A.E., Hrabik T.R., Yule D.L. \& Stockwell J.D. (2011b) Trophic connections in Lake Superior Part II: the nearshore fish community. Journal of Great Lakes Research, 37, 550-560.

Gardner W.S., Nalepa T.F., Frez W.A., Cichocki E.A. \& Landrum P.F. (1985) Seasonal patterns in lipid content of Lake Michigan macroinvertebrates. Canadian Journal of Fisheries and Aquatic Sciences, 42, 1827-1832.

Heintz R.A., Wipfli M.S. \& Hudson J.P. (2010) Identification of marine-derived lipids in juvenile coho salmon and aquatic insects through fatty acid analysis. Transactions of the American Fisheries Society, 139, 840-854.

Herbst S.J., Marsden E.J. \& Lantry B.F. (2013) Lake whitefish diet, condition, and energy density in Lake Champlain and the lower four Great Lakes following dreissenid invasions. Transactions of the American Fisheries Society, 142, 388-398.

Hoyle J.A. (2005) Status of lake whitefish (Coregonus clupeaformis) in Lake Ontario and the response to the disappearance of Diporeia spp. In: Proceedings of a Workshop on 
the Dynamics of Lake Whitefish (Coregonus clupeaformis) and the Amphipod Diporeia spp. in the Great Lakes (Eds L.C. Mohr \& T.F. Nalepa), pp. 47-66. Great Lakes Fishery Commission Technical Report 66, Great Lakes Fishery Commission, Ann Arbor, MI.

Hoyle J.A., Schaner T., Casselman J.M. \& Dermott R. (1999) Changes in lake whitefish (Coregonus clupeaformis) stocks in eastern Lake Ontario following Dreissena mussel invasion. Great Lakes Research Review, 4, 5-10.

Hrabik T.R., Jensen O.P., Martell S.J.D., Walters C.J. \& Kitchell J.F. (2006) Diel vertical migration in the Lake Superior pelagic community. I. Changes in vertical migration of coregonids in response to varying predation risk. Canadian Journal of Fisheries and Aquatic Sciences, 63, 2286-2295.

Ihssen P.E., Evans D.O., Christie W.J., Reckahn J.A. \& DesJardine R.L. (1981) Life history, morphology, and electrophoretic characteristics of five allopatric stocks of lake whitefish (Coregonus clupeaformis) in the Great Lakes region. Canadian Journal of Fisheries and Aquatic Sciences, 38, 1790-1807.

Isaac E.J. (2010) An evaluation of the importance of Mysis relicta to the Lake Superior fish community. Master of Science Thesis. University of Minnesota at Duluth, Duluth, MN.

Isaac E.J., Hrabik T.R., Stockwell J.D. \& Gamble A.E. (2012) Prey selection by the Lake Superior fish community. Journal of Great Lakes Research, 38, 326-335.

Kaufman S.D., Gunn J.M., Morgan G.E. \& Couture P. (2006) Muscle enzymes reveal walleye (Sander vitreus) are less active when larger prey (cisco, Coregonus artedi) are present. Canadian Journal of Fisheries and Aquatic Sciences, 63, 970-979.

Kelly J.R., Yurista P.M., Miller S.E., Cotter A.C., Corry T.C., Scharold J.S. et al. (2011) Challenges to Lake Superior's condition, assessment, and management: a few observations across a generation of change. Aquatic Ecosystem Health and Management, 14, 332-344.

Kiljunen M., Grey J., Sinisalo T., Harrod C., Immonen H. \& Jones R.I. (2006) A revised model for lipid-normalizing $\delta^{13} \mathrm{C}$ values from aquatic organisms, with implications for isotope mixing models. Journal of Applied Ecology, 43, 1213-1222.

Kitchell J.F., Stewart D.J. \& Weininger D. (1977) Applications of a bioenergetics model to yellow perch (Perca flavescens) and walleye (Stizostedion vitreum vitreum). Journal of the Fisheries Research Board of Canada, 34, 1922-1935.

Kline T.C. Jr, Goering J.J., Mathisen O.A., Poe P.H., Parker P.L. \& Scalan R.S. (1993) Recycling of elements transported upstream by runs of Pacific salmon: II. $\delta^{15} \mathrm{~N}$ and $\delta^{13} \mathrm{C}$ evidence in the Kvichak River watershed, Bristol Bay, southwestern Alaska. Canadian Journal of Fisheries and Aquatic Sciences, 50, 2350-2365.

Lawrie A.H. \& Rahrer J.F. (1973) Lake Superior: case history of the lake and its fisheries. Great Lakes Fishery Commission Technical Report Number 19.
Link J., Selgeby J.H. \& Keen R.E. (2004) Changes in the Lake Superior crustacean zooplankton community. Journal of Great Lakes Research, 30(Suppl. 1), 327-339.

Logan J.M., Jardine T.D., Miller T.J., Bunn S.E., Cunjak R.A. \& Lutcavage M.E. (2008) Lipid corrections in carbon and nitrogen stable isotope analyses: comparison of chemical extraction and modelling methods. Journal of Animal Ecology, 77, 838-846.

Loreau M., Mouquet N. \& Holt R.D. (2003) Meta-ecosystems: a theoretical framework for a spatial ecosystem ecology. Ecology Letters, 6, 673-679.

Lumb C.E., Johnson T.B., Cook H.A. \& Hoyle J.A. (2007) Comparison of lake whitefish (Coregonus clupeaformis) growth, condition, and energy density between Lakes Erie and Ontario. Journal of Great Lakes Research, 33, 314-325.

Lundström J., Carney B., Amcoff P., Pettersson A., Borjesön H., Förlin L. et al. (1999) Antioxidative systems, detoxifying enzymes and thiamine levels in Baltic salmon (Salmo salar) that develop M74. Ambio, 28, 24-29.

MacAvoy S.E., Macko S.E., McIninch S.E. \& Garman G.C. (2000) Marine nutrient contributions to freshwater apex predators. Oecologia, 122, 568-573.

Macpherson A., Holmes J.A., Muir A.M. \& Noakes D.L.G. (2010) Assessing feeding competition between lake whitefish Coregonus clupeaformis and round whitefish Prosopium cylindraceum. Current Zoology, 56, 109-117.

Madenjian C.P., O'Connor D.V., Pothoven S.A., Schneeberger P.J., Rediske R.R., O'Keefe J.P. et al. (2006) Evaluation of a lake whitefish bioenergetics model. Transactions of the American Fisheries Society, 135, 61-75.

Mason D.M., Johnson T.B. \& Kitchell J.F. (1998) Consequences of prey fish community dynamics on lake trout (Salvelinus namaycush) foraging efficiency in Lake Superior. Canadian Journal of Fisheries and Aquatic Sciences, 55, 1273-1284.

McConnaughy T. \& McRoy C.P. (1979) Food-web structure and the fractionation of carbon isotopes in the Bering Sea. Marine Biology, 53, 257-262.

Mohr L.C. \& Nalepa T.F. (Eds) (2005) Proceedings of a Workshop on the Dynamics of Lake Whitefish (Coregonus clupeaformis) and the Amphipod Diporeia spp. in the Great Lakes. pp. 309. Great Lakes Fishery Commission Technical Report 66, Great Lakes Fishery Commission, Ann Arbor, MI.

Munawar M. (Ed.) (1978) Limnology of Lake Superior. Journal of Great Lakes Research, 4, 3-4.

Nalepa T.F., Pothoven S.A. \& Fanslow D.L. (2009) Recent changes in benthic macroinvertebrate populations in Lake Huron and impact on the diet of lake whitefish (Coregonus clupeaformis). Aquatic Ecosystem Health and Management, 12, 2-10.

Negus M.T., Schreiner D.R., Halpern T.N., Schram S.T., Seider M.J. \& Pratt D.M. (2008) Bioenergetics evaluation of the fish community in the western arm of Lake Superior in 2004. North American Journal of Fisheries Management, 28, 1649-1667.

(C) 2014 John Wiley \& Sons Ltd, Freshwater Biology, 59, 1197-1212 
Owens R.W. \& Dittman D.E. (2003) Shifts in the diets of slimy sculpin (Cottus cognatus) and lake whitefish (Coregonus clupeaformis) in Lake Ontario following the collapse of the burrowing amphipod, Diporeia. Aquatic Ecosystem Health and Management, 6, 311-323.

Perga M.E. \& Gerdeaux D. (2005) 'Are fish what they eat' all year round? Oecologia, 144, 598-606.

Peterson B.J. \& Fry B. (1987) Stable isotopes in ecosystem studies. Annual Review of Ecology and Systematics, 18, 293320.

Phillips D.L. \& Gregg J.W. (2001) Uncertainty in source partitioning using stable isotopes. Oecologia, 127, 171-179.

Polis G.A., Anderson W.B. \& Holt R.D. (1997) Toward an integration of landscape ecology and food web ecology: the dynamics of spatially subsidized food webs. Annual Review of Ecology and Systematics, 28, 289-316.

Pothoven S.A. (2005) Changes in lake whitefish diet in Lake Michigan, 1998-2001. In: Proceedings of a Workshop on the Dynamics of Lake Whitefish (Coregonus clupeaformis) and the Amphipod Diporeia spp. in the Great Lakes (Eds L.C. Mohr \& T.F. Nalepa), pp. 127-140. Great Lakes Fishery Commission Technical Report 66, Great Lakes Fishery Commission, Ann Arbor, MI.

Pothoven S.A. \& Madenjian C.P. (2008) Changes in consumption by alewives and lake whitefish after dreissenid mussel invasions in Lakes Michigan and Huron. North American Journal of Fisheries Management, 28, 308320.

Pothoven S.A. \& Nalepa T.F. (2006) Feeding ecology of lake whitefish in Lake Huron. Journal of Great Lakes Research, 32, 489-501.

Pothoven S.A., Nalepa T.F., Schneeberger P.J. \& Brandt S.B. (2001) Changes in diet and body condition of lake whitefish in southern Lake Michigan associated with changes in benthos. North American Journal of Fisheries Management, 21, 876-883.

Rennie M.D., Sprules W.G. \& Johnson T.B. (2009) Resource switching in fish following a major food web disruption. Oecologia, 159, 789-802.

Rudstam L.G., Binkowski F.P. \& Miller M.A. (1994) A bioenergetics model for analysis of food-consumption patterns of bloater in Lake-Michigan. Transactions of the American Fisheries Society, 123, 344-357.

Saunders R., Hachey M.A. \& Fay C.W. (2006) Maine's diadromous fish community: past, present, and implications for Atlantic salmon recover. Fisheries, 31, 537-547.

Schindler D.E. \& Scheuerell M.D. (2002) Habitat coupling in lake ecosystems. Oikos, 98, 177-189.

Schmidt S.N., Olden J.D., Solomon C.T. \& Vander Zanden M.J. (2007) Quantitative approaches to the analysis of stable isotope food web data. Ecology, 88, 2793-2802.

Schmitz O.J. (2010) Predator control of ecosystem nutrient dynamics. Ecology Letters, 13, 1199-1209.

Schmitz O.J., Grabowski J.H., Peckarsky B.L., Preisser E.L., Trussell G.C. \& Vonesh J.R. (2008) From individuals to ecosystem function: toward an integration of evolutionary and ecosystem ecology. Ecology, 89, 2436-2445.

Seale D.B. \& Binkowski F.P. (1988) Vulnerability of early life intervals of Coregonus hoyi to predation by a freshwater mysid, Mysis relicta. Environmental Biology of Fishes, 21, 117-125.

Selgeby J.H. (1982) Decline of lake herring (Coregonus artedii) in Lake Superior: an analysis of the Wisconsin herring fishery, 1936-1978. Canadian Journal of Fisheries and Aquatic Sciences, 39, 554-563.

Sierszen M.E., Kelly J.R., Corry T.D., Scharold J.V. \& Yurista P.M. (2011) Benthic and pelagic contributions to Mysis nutrition across Lake Superior. Canadian Journal of Fisheries and Aquatic Sciences, 68, 1051-1063.

Sierszen M.E., Peterson G.S. \& Scharold J.V. (2006) Depthspecific patterns in benthic-planktonic food web relationships in Lake Superior. Canadian Journal of Fisheries and Aquatic Sciences, 63, 1496-1503.

Smith S.H. (1995). Early changes in the fish community of Lake Ontario. Great Lakes Fishery Commission Technical Report 60.

Stafford C.P., Hansen B. \& Stanford J.A. (2004) Mercury in fishes and their diet items from Flathead Lake, Montana. Transactions of the American Fisheries Society, 133, 349-357.

Stockwell J.D., Ebener M.P., Black J.A., Gorman O.T., Halpern T., Hrabik T.R. et al. (2009) A synthesis of cisco recovery in Lake Superior: implications for native fish rehabilitation in the Laurentian Great Lakes. North American Journal of Fisheries Management, 29, 626-652.

Stockwell J.D., Yule D.L., Gorman O.T., Isaac I.J., \& Moore S.A. (2006) Evaluation of bottom trawls compared to acoustics to assess adult lake herring (Coregonus artedi) abundance in Lake Superior. Journal of Great Lakes Research, 32, 280-292.

Stockwell J.D., Yule D.L., Hrabik T.R., Adams J.V., Gorman O.T. \& Holbrook B.V. (2007) Vertical distribution of fish biomass in Lake Superior: implications for day bottom trawl surveys. North American Journal of Fisheries Management, 27, 735-749.

Stockwell J.D., Yule D.L., Hrabik T.R., Sierszen M.E., Negus M.T., Gorman O.T. et al. (2010) Offshore fish community: ecological interactions. In: The State of Lake Superior in 2005. (Eds O.T. Gorman, M.P. Ebener \& M.R. Vinson), pp. 101-106. Great Lakes Fishery Commission Special Publication 10-01, Great Lakes Fishery Commission, Ann Arbor, MI.

Syvaränta J. \& Rautio M. (2010) Zooplankton, lipids, and stable isotopes: importance of seasonal, latitudinal, and taxonomic differences. Canadian Journal of Fisheries and Aquatic Sciences, 67, 1721-1729.

Tohtz J. (1993) Lake whitefish diet and growth after introduction of Mysis relicta to Flathead Lake, Montana. Transactions of the American Fisheries Society, 122, 629-635.

Willson M.F. \& Womble J.N. (2006) Vertebrate exploitation of pulsed marine prey: a review and the example of 
1212 J. D. Stockwell et al.

spawning herring. Reviews in Fish Biology and Fisheries, 16, 183-200.

Woodland R.J., Magnan P., Glémet H., Rodríguez M.A. \& Cabana G. (2012) Variability and directionality of temporal changes in $\delta^{13} \mathrm{C}$ and $\delta^{15} \mathrm{~N}$ of aquatic invertebrate primary consumers. Oecologia, 169, 199-209.

Young J.D. \& Yan N.D. (2008) Modification of the diel vertical migration of Bythotrephes longimanus by the cold-water planktivore Coregonus artedi. Freshwater Biology, 53, 981995.

Yule D.L., Schreiner D.R., Addison P.A., Seider M.J., Evrard L.M., Geving S.A. et al. (2012) Repeat surveys of spawning cisco (Coregonus artedi) in western Lake Superior: timing, distribution and composition of spawning stocks. Advances in Limnology, 63, 65-87.

Yule D.L., Stockwell J.D., Black J.A., Cullis K.I., Cholwek G.A. \& Myers J.T. (2008) How systematic age underestimation can impede understanding of fish population dynamics: lessons learned from a Lake Superior cisco stock. Transactions of the American Fisheries Society, 137, 481-495.

Yule D.L., Stockwell J.D., Cholwek G.A., Evrard L.M., Schram S., Seider M. et al. (2006) Evaluation of methods to estimate lake herring spawner abundance in Lake Superior. Transactions of the American Fisheries Society, 135, 680-694.

Yule D.L., Stockwell J.D., Schreiner D.R., Evrard L.M., Balge M. \& Hrabik T.R. (2009) Can pelagic forage fish and spawning-size cisco (Coregonus artedi) biomass in the western arm of Lake Superior be assessed with a single summer survey? Fisheries Research, 96, 39-50.

Zimmerman M.S. \& Krueger C.C. (2009) An ecosystem perspective on re-establishing native deepwater fishes in the Laurentian Great Lakes. North American Journal of Fisheries Management, 29, 1352-1371.

(Manuscript accepted 20 January 2014) 